\title{
Papular mucinosis of infancy
}

INSERM

\section{Source}

INSERM. (1999). Orphanet: an online rare disease and orphan drug data base. Papular mucinosis of infancy. ORPHA:90395

Papular mucinosis of infancy is a rare pediatric non progressive form of localized lichen myxedematosus (see this term) characterized by the development of firm opalescent mucinous papules on the upper arms and the trunk. 